2005-01-01

\title{
Comparison of DNA Extraction from Cervical Cells Collected in PreservCyt Solution for the Amplification of Chlamydia Trachomatis
}

\author{
Helen Keegan \\ Technological University Dublin, helen.keegan@tudublin.ie \\ Clara Boland \\ Technological University Dublin, clara.boland@tudublin.ie \\ Alison Malkin \\ Technological University Dublin, alison.malkin@tudublin.ie
}

See next page for additional authors

Follow this and additional works at: https://arrow.tudublin.ie/scschbioart

Part of the Biology Commons

\section{Recommended Citation}

Keegan, $\mathrm{H}$. et al. (2005)Comparison of DNA extraction from cervical cells collected in PreservCyt solution for the amplification of Chlamydia Trachomatis. i>Cytopathology16,pp. 82-87. doi:10.1111/

j.1365-2303.2005.00239.x

This Article is brought to you for free and open access by the School of Biological Sciences at ARROW@TU Dublin. It has been accepted for inclusion in Articles by an authorized administrator of ARROW@TU Dublin. For more information, please contact arrow.admin@tudublin.ie, aisling.coyne@tudublin.ie,gerard.connolly@tudublin.ie. 


\section{Authors}

Helen Keegan, Clara Boland, Alison Malkin, Mairead Griffin, Fergus Ryan, and Helen Lambkin 
Antenna \& High Frequency Research Centre

\title{
Articles
}

Dublin Institute of Technology

Year 2005

\section{Comparison of DNA extraction from cervical cells collected in PreservCyt solution for the amplification of Chlamydia trachomatis}

\author{
Helen Keegan* \\ Clara Boland ${ }^{\dagger}$ \\ Alison Malkin $\ddagger$ \\ Mairead Griffin** \\ Fergus Ryan Dr. ${ }^{\dagger \dagger}$ \\ Helen Lambkin ${ }^{\ddagger \ddagger}$
}

*Dublin Institute of Technology

${ }^{\dagger}$ Dublin Institute of Technology

${ }^{\ddagger}$ Dublin Institute of Technology

**St. James' Hospital

${ }^{\dagger \dagger}$ Dublin Institute of technology, fergus.x.ryan@dit.ie

$\ddagger \ddagger$ Dublin Institute of Technology

This paper is posted at ARROW@DIT.

http://arrow.dit.ie/ahfrcart/1 


\section{— Use Licence}

\section{Attribution-NonCommercial-ShareAlike 1.0}

You are free:

- to copy, distribute, display, and perform the work

- to make derivative works

Under the following conditions:

- Attribution.

You must give the original author credit.

- Non-Commercial.

You may not use this work for commercial purposes.

- Share Alike.

If you alter, transform, or build upon this work, you may distribute the resulting work only under a license identical to this one.

For any reuse or distribution, you must make clear to others the license terms of this work. Any of these conditions can be waived if you get permission from the author.

Your fair use and other rights are in no way affected by the above.

This work is licensed under the Creative Commons Attribution-NonCommercialShareAlike License. To view a copy of this license, visit:

- URL (human-readable summary):

http://creativecommons.org/licenses/by-nc-sa/1.0/

- URL (legal code):

http://creativecommons.org/worldwide/uk/translated-license 


\title{
Comparison of DNA extraction from cervical cells collected in PreservCyt solution for the amplification of Chlamydia trachomatis
}

\author{
H. Keegan*, C. Boland*, A. Malkin ${ }^{\dagger}$, M. Griffin ${ }^{\dagger}$, F. Ryan* and H. Lambkin* \\ *Molecular Biomedical Research, School of Biological Sciences, Dublin Institute of Technology and ${ }^{\dagger}$ Clinical Cytology \\ Laboratory, Department of Pathology, St James' Hospital, Dublin, Ireland \\ Accepted for publication 15 December 2004
}

H. Keegan, C. Boland, A. Malkin, M. Griffin, F. Ryan and H. Lambkin

\section{Comparison of DNA extraction from cervical cells collected in PreservCyt solution for the amplification of Chlamydia trachomatis}

Objective: The aim of this study was to compare and evaluate three methods of DNA extraction for the amplification of Chlamydia trachomatis in uterine cervical samples collected in PreservCyt solution. ThinPrep is the trade name for the slide preparation.

Methods: Thirty-eight samples collected in LCx buffer medium, which were identified as C. trachomatis infected by ligase chain reaction (LCR), were selected for this study. DNA from the PreservCyt samples was extracted by three methods: (i) QIAamp kit, (ii) boiling in Tris-EDTA buffer with Chelex purification, and (iii) Proteinase K digestion with Chelex purification. Sample DNA was tested for the presence of $C$. trachomatis by PCR using cryptic plasmid research (CTP) primers and major outer membrane protein research momp gene (MOMP) primers. Real-time (LightCycler) PCR for relative C. trachomatis quantification following DNA extraction was performed using primers (Hsp 60) for the $60 \mathrm{kDa}$ heat-shock protein $h s p 60$ gene.

Results: Amplification using CTP primers was the most successful with each of the extraction protocols. Boiling in buffer was the least successful extraction method. QIAamp was the best extraction method, yielding the most positives with both the CTP and MOMP primers. Proteinase K-Chelex extraction gave similar sensitivity to QIAamp extraction with CTP primers but lower for MOMP primers.

Conclusions: The DNA extraction method must be carefully selected to ensure that larger PCR amplicons can be successfully produced by PCR and to ensure high sensitivity of detection of $C$. trachomatis. In this study it was found that the QIAamp extraction method followed by PCR with the CTP primers was the most successful for amplification of $C$. trachomatis DNA.

Keywords: DNA extraction, cervical cells, PreservCyt, Chlamydia trachomatis, PCR, LightCycler

\section{Introduction}

Gynaecological cytology is rapidly changing due to the development of new technologies for smear preparation, automated evaluation and molecular analysis of cervical smear samples. ${ }^{1,2}$

Liquid-based cervical smear preparation is overtaking conventional smear preparation as the method

Correspondence:

Dr Helen Lambkin, School of Biological Sciences, Dublin Institute of Technology, Kevin St, Dublin 8, Ireland.

Tel.: +353 1 402 4911; Fax: +353 1402 4995;

E-mail: helen.lambkin@dit.ie of choice for cytological evaluation due to the improvement in rates of detection of preneoplastic lesions, ease of slide interpretation and decrease in number of unsatisfactory (repeat) smears., ${ }^{3,4}$ These liquid-based cervical samples are rich in cellular material, with thousands of residual cells remaining in the solution after the preparation of a monolayer smear. This cellular material is ideal for molecular analysis of both host cell genome and for detection and quantification of micro-organisms, ${ }^{5-7}$ thus offering the possibility of additional molecular tests for patients who have abnormal epithelial cells or features of inflammation on routine cytology. 
Detection of human papillomavirus in cervical samples has been exhaustively studied in both conventional and liquid-based cytology samples, ${ }^{8,9}$ however, detection and quantitation of Chlamydia trachomatis has been less thoroughly explored. ${ }^{10,11}$ Chlamydia trachomatis is an obligate intracellular bacterium which may be present in between $2 \%$ and $17 \%$ of cervical smear samples from healthy asymptomatic females depending on the population studied. ${ }^{12}$ Infection with $C$. trachomatis may result in pelvic inflammatory disease, infertility and is a major cause of ectopic pregnancy. Numerous studies have suggested that screening of young women for $C$. trachomatis would be cost effective due to the ultimate burden on the health service of the complications of this infection. ${ }^{13-15}$

The main detection methods for C. trachomatis include culture, enzyme immunoassay and nucleic acid-based techniques (NAAT). ${ }^{16}$ Recent studies indicate that the NAAT methods, which are mostly based on PCR amplification of the $C$. trachomatis cryptic plasmid sequences, offer the highest sensitivity for detection of the organism. ${ }^{17,18}$ A hybrid capture (HC) system has also been developed for Chlamydia detection, similar to the HCII system for HPV detection (Digene Corporation). ${ }^{19}$

Methods for DNA extraction from cervical cells are varied, mostly relying on some form of Proteinase $\mathrm{K}$ extraction, with or without a further purification step. ${ }^{20,21}$ Other protocols have been applied to cervical cell samples, including simple boiling in buffer, microwaving and automated DNA extraction techniques. $^{22,23}$ In this study three methods of DNA extraction from uterine cervical cell samples collected into PreservCyt solution were evaluated, by the sensitivity of detection and relative quantitation of $C$. trachomatis by molecular (PCR) amplification methods compared to a gold standard of routine cervical samples tested by LCR.

\section{Methods}

\section{Study population and clinical specimens}

Cervical samples were taken from women attending a genitourinary medicine clinic at St James' Hospital, Dublin, Ireland, and placed in LCx transport medium (LCx; Abbott Laboratories, Chicago, IL, USA). These were tested for C. trachomatis using the Ligase Chain Reaction assay (LCx; Abbott Laboratories). A second cervical sample was taken on the same visit and placed in a vial of PreservCyt medium and transported to the cytology laboratory of the hospital where a cervical smear was made. Specimens were then kept at room temperature and the DNA was extracted within 6 weeks. The sample population in this study consisted of 38 women who tested positive for C. trachomatis by the LCx.

\section{DNA extraction}

Fifteen millilitres of PreservCyt specimen was vortexed briefly and divided into three 5 -ml aliquots. These were then centrifuged at $13000 \boldsymbol{g}$ and the pellet was washed twice with TE buffer (10 mM Tris, 1 mM EDTA, pH 8.0) and resuspended in a final volume of $200 \mu \mathrm{l}$ TE buffer. In extraction method A (TE-Chelex), the cell suspension was boiled for 10 minutes with $0.1 \%$ Chelex solution (Sigma-Aldrich, St. Louis, MO, USA). In method B (Proteinase K-Chelex), the cells were resuspended in $200 \mu \mathrm{l}$ of cell lysis buffer ( $10 \mathrm{mM}$ Tris- $\mathrm{HCl}$, $400 \mathrm{mM} \mathrm{NaCl}, 2 \mathrm{mM} \mathrm{Na}{ }_{2}$ EDTA, pH 8.2), with $20 \mu \mathrm{l}$ of Proteinase $\mathrm{K}(20 \mathrm{mg} / \mathrm{ml})$ and $0.5 \%$ sodium dodecyl sulphate and incubated at $65{ }^{\circ} \mathrm{C}$ for 2.5 hours. This was then boiled for 20 minutes with $0.1 \%$ Chelex-100 solution. In method C (QIAamp), the QIAamp DNA Mini Kit (Qiagen Ltd, Crawley, UK) was used according to the manufacturer's instructions. DNA was extracted from a single sample using the three extraction methods within the same 48-hour period. Following DNA extraction samples were stored at $-20{ }^{\circ} \mathrm{C}$, until required for PCR.

PCR amplification of C. trachomatis plasmid and omp gene

The following primer sets were used for detection of C. trachomatis: a plasmid primer set (CTP $)^{24}$ (201 bp), and a primer set $(\mathrm{MOMP})^{25}$ for the major outer membrane protein gene (540 bp), (Table 1, Figure 1). PCR was performed in $20 \mu$ reaction volume, containing $2 \mu \mathrm{l}$ PCR buffer (Invitrogen Ltd, Renfrew, UK), $1.5 \mathrm{mM} \mathrm{MgCl} 2200 \mu \mathrm{M}$ of each dNTP, $25 \mathrm{pmol}$ of each primer set, $1 \mathrm{U}$ of Taq DNA polymerase (Invitrogen Ltd) and $5 \mu \mathrm{l}$ of DNA sample. The PCR reaction mixture was performed in a Hybaid Omni-E thermal cycler (Hybaid Ltd, Ashford, UK), with an initial denaturation of $95{ }^{\circ} \mathrm{C}$ for 5 minutes followed by 40 cycles of $95{ }^{\circ} \mathrm{C}$ for 1 minute, $55^{\circ} \mathrm{C}$ for 1 minute and $72{ }^{\circ} \mathrm{C}$ for 2 minutes. After 40 cycles, a further elongation step was carried out at $72{ }^{\circ} \mathrm{C}$ for 5 minutes. The products were run on a $1 \%$ agarose gel containing $0.5 \mu \mathrm{g} / \mu \mathrm{l}$ ethidium bromide. 


\begin{tabular}{|c|c|c|c|}
\hline $\begin{array}{l}\text { Gene } \\
\text { target }\end{array}$ & $\begin{array}{l}\text { Primer } \\
\text { name }\end{array}$ & $\begin{array}{l}\text { Primer } \\
\text { sequence }\end{array}$ & $\begin{array}{l}\text { Fragment } \\
\text { amplified (bp) }\end{array}$ \\
\hline \multirow[t]{2}{*}{ Plasmid } & CTP 1 & $5^{\prime}$-TAGTAACTGCCACTTCATCA-3 $3^{24}$ & \multirow[t]{2}{*}{201} \\
\hline & СТP 2 & 5'-TTCCCCTTGTAATTCGTTGC-3' & \\
\hline \multirow[t]{2}{*}{ momp } & MOMP A & 5'-TATACAAAAATGGCTCTCTGCTT-3 $3^{\prime 25}$ & \multirow[t]{2}{*}{540} \\
\hline & MOMP B & 5'-CCCATTTGGAATTCTTTATTCACATC-3' & \\
\hline \multirow[t]{2}{*}{ hsp 60} & Hsp $60 \mathrm{~F}$ & $5^{\prime}$-GATGGTGTTACCGTTGCGA-3'26 & \multirow[t]{2}{*}{650} \\
\hline & Hsp $60 \mathrm{R}$ & 5'- CCTCCACGAATTCTGTTCAC-3' & \\
\hline
\end{tabular}

Table 1. DNA oligonucleotides used for polymerase chain reaction

\section{Real-time PCR detection and quantitation of C. trachomatis DNA}

Real-time PCR for detection and quantitation of C. trachomatis was performed on all DNA samples using a primer set $(\text { Hsp } 60)^{26}$ specific for the heat-shock protein 60 gene (Table 1). An aliquot of $1 \mu \mathrm{l}$ of each sample was added to $9 \mu \mathrm{l}$ of a reaction mixture containing $3 \mathrm{mM} \mathrm{MgCl}, 0.5 \mu \mathrm{M}$ primers and $1 \mu \mathrm{l}$ of LC DNA FastSTART Master SYBR Green I enzyme mix (Roche Biochemicals, Mannheim, Germany). Samples were amplified on a LightCycler (Roche) under the following cycle conditions: an initial 10 minutes at $95{ }^{\circ} \mathrm{C}$ for activation of the FastSTART Taq DNA polymerase, followed by 40 cycles of 5 seconds of denaturation at $95{ }^{\circ} \mathrm{C}, 10$ seconds of annealing at $68{ }^{\circ} \mathrm{C}$, decreasing to $65{ }^{\circ} \mathrm{C}$ at a rate of $1{ }^{\circ} \mathrm{C} /$ cycle and 30 seconds of extension at $72{ }^{\circ} \mathrm{C}$. Data were obtained after the extension period in the single acquisition mode. The Hsp 60 PCR product was cloned into a pBSII vector and serially diluted cloned copies were used to create a standard curve $\left(10^{5}\right.$ to $10^{2}$ copies) for quantitation of chlamydial copy numbers. These standards were run with each LightCycler run and a calculation of C. trachomatis copy numbers was taken by the machine at the crossing point of each sample during the exponential phase of amplification. A melt curve step was included to confirm the amplification. Samples which gave copy numbers outside the range of the standards or whose melt-temperature $\left(T_{\mathrm{m}}\right)$ was outside those of the standards had their real-time PCR product analysed by agarose gel electrophoresis. A sample was positive if amplification of the $650 \mathrm{bp}$ product occurred during the amplification programme of 40 cycles.

\section{Results}

DNA isolated from the 38 LCx-positive samples by the three extraction protocols was analysed for C. trachomatis positivity by PCR and real-time PCR and quantified using real-time PCR. A positive result for either the CTP or the MOMP primer set was determined by the presence of $201 \mathrm{bp}$ product for the CTP primer set and a 540-bp product for the MOMP primer set on agarose gel electrophoresis. The Hsp 60 real-time PCR assay was positive if quantified C. trachomatis copy numbers were inside the range of the standards or if running of the product on an agarose gel gave the required $650 \mathrm{bp}$ product size. 5 TE-Chelex, 5 Proteinase K-Chelex, and 2 QIAamp samples had copy numbers below the range of the standards $(<100)$ but were positive on gel electrophoresis of the PCR product.

Detection of C. trachomatis by plasmid, major outer membrane protein and heat-shock protein 60 real-time PCR

Ninety-five percent (36/38) of samples extracted using either the TE-Chelex method or the Proteinase K-Chelex method were positive for C. trachomatis by either of the three PCRs. The QIAamp samples gave a slightly higher overall positivity rate of $97 \%$ (37/38) with a sensitivity of $95 \%$ for detection using plasmid PCR, $90 \%$ by MOMP PCR and $95 \%$ by Hsp 60 realtime PCR (Table 2). Of the QIAamp samples 90\% (34/ 38 ) amplified for each of the three PCRs as opposed to $71 \%(27 / 38)$ of the Proteinase K-Chelex samples and only 50\% (19/38) of the TE-Chelex samples (Table 2). The plasmid primers were the most successful for the amplification of C. trachomatis DNA extracted by each of the three methods, followed by the Hsp 60 primer set and then the MOMP primer set (Table 2).

\section{Real-time LightCycler PCR analyses of C. trachomatis copy numbers}

Real-time quantitation of $C$. trachomatis copy numbers in samples was carried out to determine if reduced sensitivity of detection by PCR was associated with low copy numbers of the organism and to determine the relative yield of $C$. trachomatis copy numbers for each extraction method. 


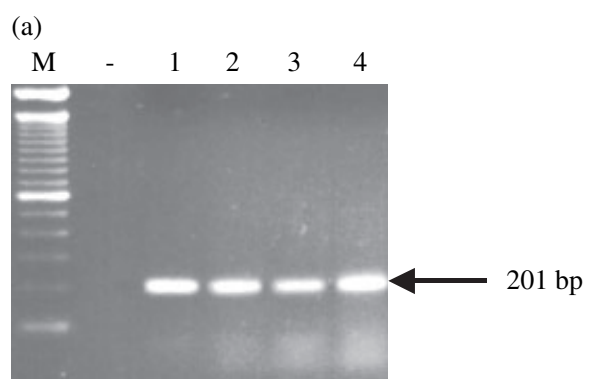

(b)

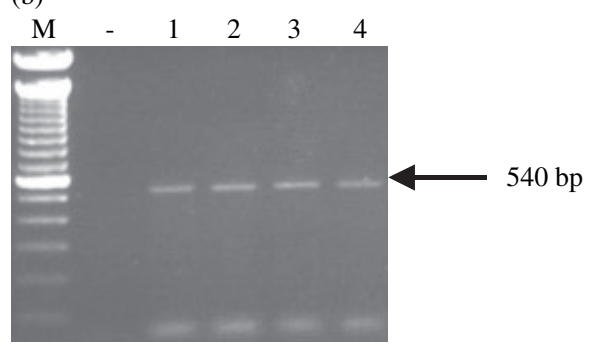

(c)

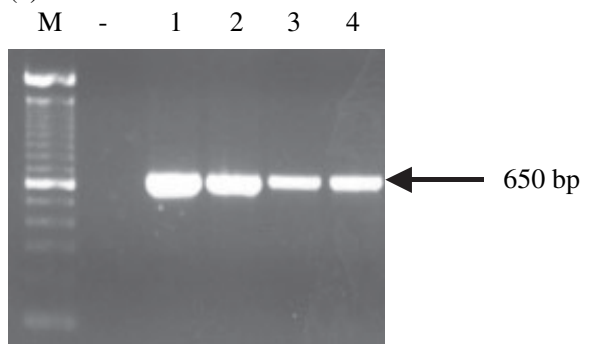

Figure 1. (a) Examples of PCR amplification of a region of Chlamydia trachomatis plasmid (201 bp) using the CTP primer set. (b) Examples of PCR amplification of C. trachomatis major outer membrane protein gene (540 bp) using the MOMP primer set. (c) Examples of PCR amplification of the $C$. trachomatis heat-shock protein 60 gene $(650 \mathrm{bp})$ using the Hsp 60 primer set. $\mathrm{M}=100 \mathrm{bp}$ DNA marker; -: negative control; 1: positive control; 2-4: different samples.

The QIAamp and the Proteinase K-Chelex samples most commonly gave copy numbers of $10^{4} / \mu \mathrm{l}$ of extracted DNA as opposed to the TE-Chelex samples which gave a lower yield of $10^{2} / \mu$ l of extracted DNA (Table 2). The distribution of copy numbers was evenly spread for the Proteinase K-Chelex samples, when compared with the TE-Chelex and QIAamp samples, which had copy numbers concentrated at the lower and upper end of the range respectively (Table 2).

Negative results by the plasmid and the MOMP PCRs were frequently associated with low copy numbers. Of the four TE-Chelex extracted samples negative by plasmid PCR, three were below the
Table 2. Comparison of positive PCR results for each extraction method using the CTP, MOMP and Hsp 60 primers, with quantification of Chlamydia trachomatis copy numbers by Hsp 60 real-time PCR

\begin{tabular}{|c|c|c|c|}
\hline \multirow[b]{2}{*}{ Primer set } & \multicolumn{3}{|c|}{ No. of positive tests* } \\
\hline & TE-Chelex $(\%)^{\dagger}$ & PK-Chelex $(\%)^{\ddagger}$ & QiAmp $(\%)^{\mathrm{S}}$ \\
\hline СТP & $34(90)$ & $35(92)$ & $36(95)$ \\
\hline MOMP & $23(61)$ & $28(74)$ & $34(90)$ \\
\hline Hsp 60 & $28(74)$ & $32(84)$ & $36(95)$ \\
\hline 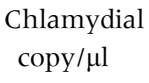 & \multicolumn{3}{|c|}{ No of positive tests in each copy number level } \\
\hline$<100$ & 5 & 5 & 2 \\
\hline $10^{2}$ & 14 & 6 & 8 \\
\hline $10^{3}$ & 6 & 6 & 11 \\
\hline $10^{4}$ & 2 & 8 & 13 \\
\hline $10^{5}$ & 1 & 6 & 2 \\
\hline $10^{6}$ & 0 & 1 & 0 \\
\hline
\end{tabular}

*All samples in the study were $C$. trachomatis positive by the LCx assay.

${ }^{\dagger}$ Boiling in Tris-EDTA buffer followed by Chelex purification. 'Proteinase K digestion followed by Chelex purification.

${ }^{\S}$ QIAamp DNA extraction kit.

detection level of 100 copies of $C$. trachomatis/ $\mu$ of extracted DNA and of the 15 MOMP-negative samples three samples had $<1000$ copies and 12 had $<100$ copies of $C$. trachomatis by quantitative PCR. Of the four QIAamp samples which did not amplify for all three genes, one sample was positive by Hsp 60 realtime PCR only, with a copy number of $10^{2}$. The other two amplified for the plasmid but not the momp gene; the real-time PCR result was negative for one and copy numbers $<100 / \mu \mathrm{l}$ DNA for the other).

\section{Discussion}

The advent of liquid-based cervical cytology may enable gynaecologists to screen for both cervical preneoplastic lesions and sexually transmitted infectious agents from the same sample. This is based on the ability of liquid-fixed cells to yield nucleic acids suitable for molecular-based assays. ${ }^{27,28}$ There are a growing number of publications using PreservCyt specimens for molecular detection of organisms including HPV, herpes simplex viruses, Trichomonas vaginalis and C. trachomatis. ${ }^{29,30}$ As DNA extracted from PreservCyt specimens may be used to screen for multiple organisms there is a need for the development of simple rapid inexpensive DNA extraction methods, 
which can readily be applied in the diagnostic setting. The main aim of this study therefore was to compare the efficiency of two inexpensive in-house DNA extraction procedures (Tris-EDTA-Chelex and Proteinase K-Chelex) and one kit-based method (QIAamp) for the detection of $C$. trachomatis by PCR.

The results of this study indicate that the commercial QIAamp extraction kit was the most successful extraction method for amplification of the three different target genes, but that the Proteinase K-Chelex method had a similar success rate for C. trachomatis amplification when the plasmid primers were used. However, amplification of larger PCR products was less successful from Proteinase K-Chelex than with the commercial extraction kit which would have implications for application of other molecular methods, particularly restriction enzyme digestion for restriction fragment length polymorphism analysis.

In this study there was $90 \%, 92 \%$ and $95 \%$ sensitivity of C. trachomatis detection by plasmid PCR amplification by TE-Chelex, Proteinase K-Chelex and QIAamp respectively. Koumans et al. also analysed PreservCyt samples for C. trachomatis detection using a commercial extraction and detection system and reported $97 \%$ sensitivity for $C$. trachomatis detection. ${ }^{11}$ On comparison of commercial DNA extraction kits QIAamp has been reported as the most successful. ${ }^{31}$ In this study amplification for the plasmid gene was the most successful method for detection of $C$. trachomatis and showed the greatest concordance for the three extraction methods. Other studies have shown that plasmid primers are more sensitive than MOMP primers for the detection of $C$. trachomatis due to the presence of multiple plasmids per organism. ${ }^{32,33}$

Some studies have reported lack of reproducibility of C. trachomatis detection, even with commercial systems, and recommend duplicate samples or the application of two NAAT detection methods. ${ }^{34}$ In this study all samples were amplified for three different genes to increase the specificity of detection. This study recommends the combined use of the plasmid and heat-shock protein 60 gene primers for PCR detection of $C$. trachomatis.

Real-time PCR is a fast and effective way for the detection and quantitation ${ }^{35}$ of bacterial load in clinical samples and for validation of DNA extraction methods. Real-time PCR quantitation was used in this study to show that a drop off in sensitivity of detection, particularly for the larger PCR products, was associated with low copy numbers of $C$. trachomatis.
This study shows that a single PreservCyt cervical specimen can be used as a source of high quality DNA for testing for sexually transmitted infections. Optimization of the method of DNA extraction from PreservCyt is essential to avoid false negatives and ensure adequate sensitivity of detection. Careful selection of genes to be amplified and the PCR product size for the detection of $C$. trachomatis is recommended. Real-time PCR quantitation is a valuable method for validation of the sensitivity of PCR detection methods.

\section{Acknowledgments}

This work was funded by the Research Support Unit, Dublin Institute of Technology, Ireland. We thank the staff of the St James' Hospital, Dublin (Clinical Cytology Laboratory), for their assistance in sample collection, and Dr Fiona Mulcahy of the GUIDE Clinic, St James' Hospital, Dublin, for her cooperation in the study.

\section{References}

1. Costa S, Sideri M, Syrjanen K et al. Combined Pap smear, cervicography and HPV DNA testing in the detection of cervical intraepithelial neoplasia and cancer. Acta Cytol 2000;44:310-8.

2. Alasio LM, Alphandery C, Grassi P et al. Performance of the AutoPap Primary Screening System in the detection of high-risk cases in cervicovaginal smears. Acta Cytol 2001;45:704-8.

3. Monsonego J, Autillo-Touati A, Bergeron C et al. Liquidbased cytology for primary cervical cancer screening: a multi-centre study. Br J Cancer 2001;84:360-6.

4. Wang N, Emancipator SN, Rose P, Rodriguez M, AbdulKarim FW. Histologic follow-up of atypical endocervical cells. Liquid-based, thin-layer preparation vs. conventional Pap smear. Acta Cytol 2002;46:453-7.

5. Murphy N, Ring M, Killalea AG et al. pl6INK4A as a marker for cervical dyskaryosis: CIN and CGIN in cervical biopsies and ThinPrep smears. J Clin Pathol 2003;56: 56-63.

6. Cubie HA, Seagar AL, McGoogan E et al. Rapid real time PCR to distinguish between high risk human papillomavirus types 16 and 18. Mol Pathol 2001;54:24-9.

7. Tucker RA, Unger ER, Holloway BP et al. Real-time PCR-based fluorescent assay for quantitation of human papillomavirus types 6, 11, 16, and 18. Mol Diagn 2001;6: 39-47.

8. Schiffman M, Castle PE. Human papillomavirus: epidemiology and public health. Arch Pathol Lab Med 2003;127: 930-4.

9. van Duin M, Snijders PJ, Schrijnemakers HF et al. Human papillomavirus 16 load in normal and abnormal cervical 
scrapes: an indicator of CIN II/III and viral clearance. Int $J$ Cancer 2002;98:590-5.

10. Bianchi A, Moret F, Desrues M et al. PreservCyt transport medium used for the ThinPrep Pap test is a suitable medium for detection of Chlamydia trachomatis by the COBAS Amplicor CT/NG test: results of a preliminary study and future implications. $J$ Clin Microbiol 2002;40:1749-54.

11. Koumans EH, Black CM, Markowitz LE et al. Comparison of methods for detection of Chlamydia trachomatis and Neisseria gonorrhoeae using commercially available nucleic acid amplification tests and a liquid pap smear medium. J Clin Microbiol 2003;41:1507-11.

12. Wilson JS, Honey E, Templeton A et al. A systematic review of the prevalence of Chlamydia trachomatis among European women. Hum Reprod Update 2002;8:385-94.

13. Howell MR, Quinn TC, Gaydos CA. Screening for Chlamydia trachomatis in asymptomatic women attending family planning clinics. A cost-effectiveness analysis of three strategies. Ann Intern Med 1998;128:277-84.

14. Howell MR, Quinn TC, Braithwaite W, Gaydos CA. Screening women for Chlamydia trachomatis in family planning clinics: the cost-effectiveness of DNA amplification assays. Sex Transm Dis 1998;25:108-17.

15. Howell MR, Gaydos JC, McKee KT Jr, Quinn TC, Gaydos CA. Control of Chlamydia trachomatis infections in female army recruits: cost-effective screening and treatment in training cohorts to prevent pelvic inflammatory disease. Sex Transm Dis 1999;26:519-26.

16. Black CM. Current methods of laboratory diagnosis of Chlamydia trachomatis infections. Clin Microbiol Rev 1997; 10:160-84.

17. Pasternak R, Vuorinen P, Pitkajarvi $\mathrm{T}$ et al. Comparison of manual amplicor PCR, Cobas Amplicor PCR, and LCX assays for detection of Chlamydia trachomatis infection in women by using urine specimens. J Clin Microbiol 1997;35:402-5.

18. Land S, Tabrizi S, Gust A et al. External quality assessment program for Chlamydia trachomatis diagnostic testing by nucleic acid amplification assays. $J$ Clin Microbiol 2002;40:2893-6.

19. Girdner JL, Cullen AP, Salama TG et al. Evaluation of the digene hybrid capture II CT-ID test for detection of Chlamydia trachomatis in endocervical specimens. J Clin Microbiol 1999;37:1579-81.

20. Gopalkrishna V, Francis A, Sharma JK, Das BC. A simple and rapid method of high quantity DNA isolation from cervical scrapes for detection of human papillomavirus infection. $J$ Virol Methods 1992;36: 63-72.

21. Jacobs MV, Zielinski D, Meijer CJ et al. A simplified and reliable HPV testing of archival Papanicolaou-stained cervical smears: application to cervical smears from cancer patients starting with cytologically normal smears. Br J Cancer 2000;82:1421-6.
22. Lou YK, Qin H, Molodysky E, Morris BJ. Simple microwave and thermal cycler boiling methods for preparation of cervicovaginal lavage cell samples prior to PCR for human papillomavirus detection. $J$ Virol Methods 1993;44:77-81.

23. Cuschieri KS, Seagar AL, Moore C et al. Development of an automated extraction procedure for detection of human papillomavirus DNA in liquid-based cytology samples. J Virol Methods 2003;107:107-13.

24. Griffais R, Thibon M. Detection of Chlamydia trachomatis by the polymerase chain reaction. Res Microbiol 1989;140:139-41.

25. Mittal A. Serovar distribution of Chlamydia trachomatis isolates collected from the cervix: use of the polymerase chain reaction and restriction endonuclease digestion. $\mathrm{Br}$ J Biomed Sci 1998;55:179-83.

26. Wood H, Reischl U, Peeling RW. Rapid detection and quantification of Chlamydia trachomatis in clinical specimens by LightCycler PCR. In: Rapid Cycle Real-Time PCR Methods and Applications. Reischl U, Witter C, Cockerill F (eds). New York: Springer; 2002: 115 pp.

27. Habis AH, Vernon SD, Lee DR, Verma M, Unger ER. Molecular quality of exfoliated cervical cells: implications for molecular epidemiology and biomarker discovery. Cancer Epidemiol Biomarkers Prev 2004;13:492-6.

28. Tarkowski TA, Rajeevan MS, Lee DR, Unger ER. Improved detection of viral RNA isolated from liquidbased cytology samples. Mol Diagn 2001;6:125-30.

29. Lanham S, Herbert A, Basarab A, Watt P. Detection of cervical infections in colposcopy clinic patients. J Clin Microbiol 2001;39:2946-50.

30. Fiel-Gan MD, Villamil CF, Mandavilli SR et al. Rapid detection of HSV from cytologic specimens collected into ThinPrep fixative. Acta Cytol 1999;43:1034-8.

31. Berg HF, Maraha B, Bergmans AM et al. Extraction of Chlamydia pneumoniae DNA from vascular tissue for use in PCR: an evaluation of four procedures. Clin Microbiol Infect 2003;9:135-9.

32. Mahony JB, Luinstra KE, Sellors JW, Chernesky MA. Comparison of plasmid- and chromosome-based polymerase chain reaction assays for detecting Chlamydia trachomatis nucleic acids. J Clin Microbiol 1993;31:1753-8.

33. Roosendaal R, Walboomers JM, Veltman OR et al. Comparison of different primer sets for detection of Chlamydia trachomatis by the polymerase chain reaction. J Med Microbiol 1993;38:426-33.

34. Castriciano S, Luinstra K, Jang D et al. Accuracy of results obtained by performing a second ligase chain reaction assay and PCR analysis on urine samples with positive or near-cutoff results in the LCx test for Chlamydia trachomatis. J Clin Microbiol 2002;40:2632-4.

35. Tondella ML, Talkington DF, Holloway BP et al. Development and evaluation of real-time PCR-based fluorescence assays for detection of Chlamydia pneumoniae. J Clin Microbiol 2002;40:575-83. 
Copyright of Cytopathology is the property of Blackwell Publishing Limited and its content may not be copied or emailed to multiple sites or posted to a listserv without the copyright holder's express written permission. However, users may print, download, or email articles for individual use. 